\title{
Extensive livestock farming in Morocco: From marginal territories to major social and environmental roles
}

\author{
Mohamed Taher Sraïri ${ }^{1}$
}

\section{Keywords}

Sheep, poultry, dairy cattle, pastoralism, extensive husbandry, product quality, intensive farming, breed, Morocco

Accepted: 21 December 2014; Published: 25 March 2016

\begin{abstract}
Summary
Recent developments in the supply of animal products in Morocco revealed a sharp decline of the contribution of extensive livestock farming systems. In a context of marked demographic expansion (from 15.3 to 32.9 million inhabitants from 1956 to 2013) associated to rapid urbanization (almost 60\% of the population lives in urban centers), consumption habits have changed. There has been a shift from a patriarchal structure of the society, which meant that meals were consumed at home, to more individualistic behaviors. As a consequence, the nature of animal products consumed by large sections of the population has notably changed. Dairy and poultry products appear to be most suited to these changes, as they can easily be used in fast-food preparations. On another hand, the consumption of beef and mutton from extensive systems has been stagnating. Extensive livestock systems, however, still use many fibrous feeds, from rangeland resources to cereal by-products. Traditionally, this has enabled them to ensure strategic functions such as the regional development of marginal areas, natural resource management, efficient water productivity through livestock products in a country experiencing acute water scarcity, and the creation of wealth and job opportunities. The shift of interest from these systems to more intensive ones raises many questions. It puts tremendous pressure on natural resources in areas of intensive production. In addition, the supply of animal products has become highly fragile as it depends on imported inputs, from animal genes to feeds (e.g. soya and maize for poultry). These changes mean that more attention should be given to extensive livestock production systems, as they promote a greener way of production and enhance large rural areas. These systems will hold a strategic position in the near future, when the time comes to face issues such as sustainability of the animal protein supply and natural resource preservation, and to balance the development of the various regions of the country.
\end{abstract}

- How to cite this article: Sraïr M.T., 2015. Extensive livestock farming in Morocco: From marginal territories to major social and environmental roles. Rev. Elev. Med. Vet. Pays Trop., 68 (2-3): 123-128
1. Department of Animal Production and Biotechnology, Hassan II Institute of Agronomy and Veterinary Medicine, PO Box 6202, Madinate Al Irfane, Rabat, Morocco.

Tel.: +212 5377717 58; Email: mt.srairi@iav.ac.ma

\section{INTRODUCTION}

Located in the Western part of North Africa, Morocco stretches from the Atlantic Ocean to the Sahara Desert. It presents a wide variety of agricultural ecosystems that include rain-fed Atlantic plains, large scale irrigation schemes, Atlas and Mediterranean mountainous zones, oasis, and desert areas (Figure 1). The country is mainly characterized by its semiarid to arid climate, which constitutes an acute challenge to secure food supply. As a consequence, the country has become a net importer of food, mainly cereal grains: in 2013, more than 2.8 million tons of wheat were imported and cost 990 million US\$ (OCC, 2013). 
Bioclimatic areas

1. Subhumid area

2. Atlantic semiarid area

3. Atlantic arid area

4. Mountain semiarid area

5. Mediterranean arid area

6. Bush arid area

7. Mountain arid area

8. Northern Atlantic arid area

9. Saharan arid area

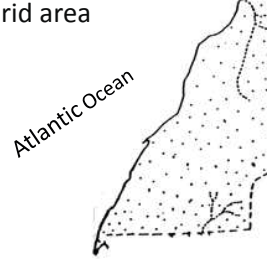

Figure 1: Bioclimatic areas of Morocco.

The wide diversity of agroecosystems promoted the emergence of contrasted breeds of ruminants. Animal wealth has traditionally assumed various vital roles, from the control of rangeland territories to the supply of animal proteins. In fact, as a human society which used to have a strong tribal structure, the livestock has always represented a privileged way of using natural resources (Miège, 1961). During the colonization period, animal products were intensively coveted by ruling powers at a time when Europe was at war. In fact, Morocco was famous for its leather and mutton from extensive pastoral systems (Vaysse, 1952). The country is also the cradle of the Merino sheep breed, which was originally exported during the Merinids dynasty, which prevailed from 1269 to 1465 . This breed became popular in Europe and spread worldwide, as it became a major producer of high quality wool (Flamant, 2002).

The original extensive livestock production systems proved their adaptation to numerous vital functions. In the entire North African region, in periods of intense drought or during political unrest, breeders used to keep a limited number of reproductive females to reconstitute their herds after the climatic and/or sociopolitical situation returned to normal (Tillon, 2000).

These strategies seemed well adapted to a context of limited demographic expansion. In periods of intense trouble, such strategies would not however be sufficient to prevent huge mortality rates in herds and animal product shortages (Lakrakeze, 1993). At the end of the colonial episode in 1956, it became obvious that the rapid growth of the human population associated with changing living standards posed a real challenge to secure the supply of animal proteins. Sound policies devoted to livestock production had to be elaborated and implemented.

This paper focused on the consequences of these livestock policies on the supply of animal products in Morocco and their recent effects on traditional extensive systems. An analysis of the evolution of the demand of animal products is presented, the impacts of the adopted livestock policies have been assessed, and the consequences on extensive systems have been detailed.

\section{- RECENT DEMOGRAPHIC CHANGES IN MOROCCO AND THEIR IMPACTS}

Morocco has experienced marked demographic changes during the 20th century. From 1956 to 2013, the Moroccan population more than doubled (from 15.3 to 32.9 million inhabitants). During the same period, the urbanization rate increased from 27.8 to $55.1 \%$ (Catin et al., 2007). This marked increase has created an unbalanced development of the country, with the megalopolis of Casablanca alone concentrating more than $20 \%$ of the whole population.

These rapid evolutions have induced new social needs that include food, housing and job opportunities. The rapid urbanization has also brought about changes in traditional living patterns. For instance, the society structure, which can be traced to tribes mainly living on rain-fed cereal crops coupled to extensive sheep production, has shifted to more individualistic behaviors in big cities. Consumption habits have thus changed from collective meals eaten at home (tajine), to individual meals often consumed outside. Therefore, the demand for food and its structure have changed noticeably. This has led to the progressive and worrying emergence of metabolic diseases such as diabetes and obesity (Rguibi and Belahsen, 2007). Particularly, mutton, which used to be the most popular kind of meat, has been rapidly losing ground to poultry, whereas beef consumption stagnates (Sarter, 2006). Mutton is being more and more perceived as a source of health trouble because of its high cholesterol content. In addition, mutton and beef prices being more than double that of broiler meat penalize red meat consumption. Finally, mutton does not seem adapted enough for use in fast-food meals such as sandwiches and pizzas. It has gained however the status of a festive meat associated to social and religious celebrations such as baptism, wedding and above all the sacrifice of Prophet Ibrahim's son, Ismail, locally known as the Aïd El Kébir (Sraïri, 2011). The latter imposes to each male adult Muslim to sacrifice once a year a well-conformed lamb. Given the average income of the Moroccan population, the mean annual consumption of animal products remains low with less than $50 \mathrm{~kg}$ of dairy products, $28.6 \mathrm{~kg}$ of meat (4.9 of mutton and goat, 6.4 of beef, and 17.3 of poultry), with marked individual variations. Therefore, significant increases in meat consumption might be expected in relation with improvements of household incomes.

\section{- LIVESTOCK POLICIES AND THEIR EFFECTS ON THE ANIMAL PRODUCT SUPPLY}

\section{Sudden emergence of intensive poultry}

The first measure that increased the animal product supply was the launching of private poultry farms in the early 1960s. These facilities settled near the main port of Casablanca, as the country does not produce maize and soya which are necessary for this kind of business. Imports of maize grain have been increasing rapidly, from 0.1 to 1.8 million ton between 1981 and 2013 (OCC, 2013). In 2013, this gross expense represented more than 343 million US\$. Today, poultry products from modern facilities constitute $58 \%$ of total meat and $90 \%$ of eggs consumed by Moroccans. Hence, the poultry sector has been in the spotlight to ensure the sufficient supply of animal products following a global trend (Speedy, 2003), unlike the ruminant sector. The modern poultry sector has experienced sustained growth in the production of eggs (from 201 to 4300 million units from 1980 to 2013) and broiler meat (from 70,000 to 510,000 tons during the same period) (FIS, 2008). Poultry products represent a handy source of proteins to a large spectrum of society, as their prices and availability are not affected by climate hazards .

However, the poultry sector in Morocco contains several weak points among which it is highly dependent on imported feeds and genes. It is also highly vulnerable to heat stress which commonly 
affects the country during summer. In fact, in such periods locally known as chergui, even night temperatures may be above $50^{\circ} \mathrm{C}$ during two to three consecutive days, causing high mortality rates and decreased animal performances. Moreover, the avian influenza crisis had tremendous effects on the sector, ruining many farmers. Lastly, the vast majority of poultry facilities settled in areas which were engulfed later on by big cities. This causes many problems related to excreta and dead animal management.

\section{Difficulties to implement modern dairying in smallholder farms}

The adoption of a 'Dairy Plan' represented another significant step to increase the availability of animal products in Morocco. Such a plan was officially launched in 1975 and relied on several measures: i) the imports of heifers and the encouragement of crossbreeding between local and specialized dairy breeds, ii) the development of fodder crops, iii) the implementation of a milk collection policy to allow smallholder farmers to get a regular income, and iv) the taxation of imported dairy product, to ensure competitiveness of local products. This strategy successfully boosted milk production, which steadily increased from 1970 to 2012 (Figure 2).

However, climatic hazards have affected production, particularly during the drought periods of 1980-82 and 1991-92. Moreover, since the early 1980s, structural adjustment programs affected the State intervention in the dairy chain, which meant the rapid collapse of all kinds of incentives to dairy producers. This rapidly prompted the increase of input prices (feed, but also those of services such as artificial insemination) at a time when the farm gate milk price was stagnating. These changes implied that the dairy activity had to manage growing difficulties, from soaring prices of strategic feeds (above all imported cereal grains and proteinaceous meals) to water stress. Therefore, cattle farmers' average gross margin from this activity has remained generally low (less than 200 US\$ per cow per year, including calf crop sales) and has been very variable, from positive results to deficits (Sraïri et al., 2009b).

The decisive factors which affect the average milk yield per cow in a herd are, firstly, sufficient feed availability (in addition to fodder) and, secondly, its use within balanced dietary rations, as farmers often ignore the principles ruling ruminant feeding. In addition, in a country where water availability is scarce (below 800 cubic meters per capita per year), the agricultural sector will have to deal in the near future with enormous challenges to manage this resource efficiently (Blinda and Thivet, 2009). With regards to dairying, water productivity through cattle rearing is

$$
\text { Tons }
$$

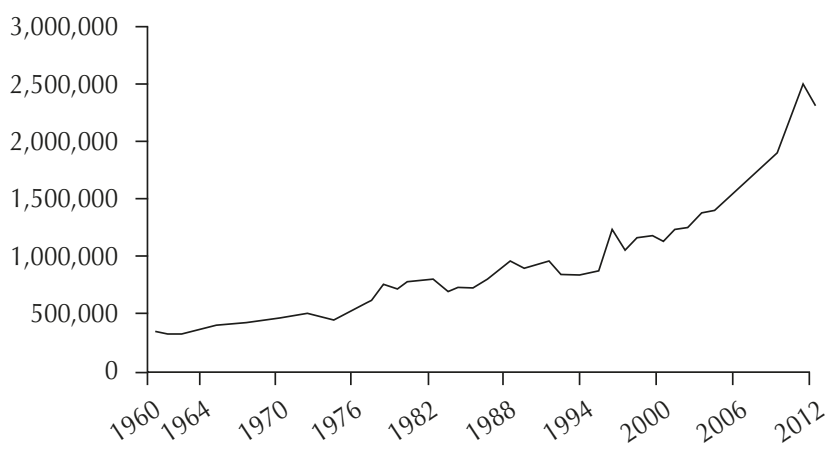

Figure 2 : Milk output in Morocco from 1960 to 2012. crucial, as more than $60 \%$ of total milk volumes originates from large scale irrigation schemes which represent less than $15 \%$ of the arable land of the country.

The study of water productivity through the herds constitutes a complex task as it requires analyzing a series of production functions: i) from water volumes entering fodder plots, ii) to fodder quantities produced within these plots, and eventually the amounts of 'virtual water' (Allan, 1998) represented by off-farm feed resources, and iii) to cattle products, which are in the case of the vast majority of farms, both milk and live weight gain, as herds are generally dual purpose (Le Gal et al., 2009). A series of on-farm research was conducted recently in a large scale irrigation scheme in Morocco to assess water productivity through cattle farming. Results showed that almost 1.8 cubic meter of water was necessary to obtain one kilogram of milk, whereas 16.5 cubic meters of water were used to produce one kilogram of beef (Sraïri et al., 2009c). These values were higher than the international standards of water footprint to get milk and meat (Chapagain and Hoekstra, 2004). In the case of Morocco these data however reveal that more attention needs to be paid to that issue, as the water used often comes from groundwater sources, which may be depleted if no regulation mechanisms are adopted to ensure their sustainability (Hammani et al., 2009).

The analysis of the series of production functions to convert water to cattle products revealed that large margins of improvement existed within farms to increase water productivity. Interventions may target irrigation systems (from gravity systems to drip irrigation), fodder biomass yield (by generalizing sound agricultural practices), fodder species (for instance by replacing alfalfa, which is a perennial crop, with maize, which only has a four-month cycle) and finally animal feeding (the systematic use of balanced dietary rations). All these measures however require sound technology transfer tools to farmers, so that the latter can adopt these changes. During this research, a program tested the effects of monitoring closely the feeding practices of five herds. It showed that the average milk yield per cow could be significantly increased by just providing correct advice to farmers: matching the nutrient supply of dietary rations with the energetic and protein levels needed for the potential production of lactating cows (Sraïri et al., 2011).

Another significant challenge which will affect the dairy sector in Morocco relates to milk quality management. In a context where smallholder farms represent the main contributors to the output, the daily production has to transit through cooperative collecting centers to decrease logistic costs before processing. This twostage chain shows obvious limitations to assess the quality of each single batch (Sraïri et al., 2009a). In such a system, it is impossible to reward farmers individually for good quality milk and to penalize those for poor one because the costs of analyses would be, for the vast majority of the batches that are delivered daily, higher than their market value as many farmers bring less than ten liters per day to the collection centers. Therefore, milk quality and its fair payment also are a sensitive issue for the dairy chain, as they can cause tension between farmers and dairy processors.

As a whole, modern dairying in Morocco will face many major challenges in the near future, particularly as the country is negotiating free-trade with the European Union. As the pressure on water sources is getting more intense, particularly because of the expected effects of climate change and of the fragmented structure of the chain, targeted measures will be needed to ensure competitiveness. This will require further measures to upgrade the whole dairy chain, from human resources to a fair value distribution chain that will benefit all operators. 


\section{Changes in the traditional livestock systems of marginal areas}

Apart from intensive poultry and dairy cattle, animal husbandry in Morocco has always been interested in extensive livestock production. There is a very old tradition of camel, sheep and goat breeding on wide rangelands, whereas cattle are more associated to cultivated areas. Because of the numerous agroecosystems present in the country, there are many breeds of these species that have been naturally selected. Three main cattle breeds (Oulmés-Zaër, Atlas Brown, and Tidili) have been identified and they are all highly adapted to harsh environments (shrinking feed supplies caused by summer droughts) through physiological abilities, but their potential milk yield and growth traits remain limited. Therefore, their main production goal is calf crop, as farmers aim at getting an average of one calf per cow. This is hardly achieved because of common reproduction failures associated to frequent nutritional imbalances in herds, particularly during summer or in periods of drought (Haddada et al., 2003).

Morocco is also known for sheep production, with more than 17.5 million head. The country almost produced 120,400 metric tons of mutton in 2008, and this product ranked seventh among the other agricultural products of the country in term of value, i.e. 238 million US\$ (FAO, 2010). Six endogenous sheep breeds have been identified, each associated to a specific territory with particular feed resources. In addition, there are numerous sheep populations in marginal areas which have not been sufficiently studied yet. This animal wealth represents a crucial asset, as it constitutes the only way to get a source of income from shrubs and poor vegetation. Sheep provide in these regions a vast array of products, not only high quality meat, but also wool which used to represent a high value product as it allowed local handicraft to develop (mainly carpet production), and above all manure, which is important for soil fertility management in systems generally not using fertilizers. Therefore, in high altitude sheep barns, manure is collected throughout the year and transported on mules to villages, where intensive crop cultivation is practiced (Bourbouze, 1997).

Previous works on sheep production in Morocco conclude that three distinct systems may be identified: i) extensive pastoral systems, which mainly depend on rangeland throughout the year, with a very limited contribution from cultivated resources; ii) agropastoral systems, which rely on both rangeland and cultivated resources (cereal straw, stubbles and grains, and sometimes fodder) and even extra farm resources (compound feed); and iii) oasis systems, which use mainly local feed resources (alfalfa, wheat straw and date residues) to raise a famous prolific breed (D'man) within small flocks (less than five ewes with their progeny) as feed availability is limited in such a context (Boulanouar and Paquay, 2005).

Recent developments in sheep production systems in Morocco however recognize that there has been a shift toward two marked changes. The first one reveals that in all the flocks there has been a trend toward increasing cereal grain use because price policies tend to encourage mutton meat production through the import of cheap grains, above all barley (Table I). Such choices have led to a growing animal load in many rangelands, which raises concerns on natural resource management (vegetation and soil erosion) in fragile areas. This is particularly true in the arid areas east and south of the country, which represent the majority of rangeland territories (Chiche, 2008).

The second development consists in the emergence of the religious ceremony of Aïd El Kébir as the main market for lambs (Alary and Boutonnet, 2006), as this ceremony concentrates more than
$50 \%$ of all the sheep slaughtered annually. Therefore, sheep farmers have to adapt to this specific market. Purchases of sheep destined to this ceremony follow strict religious specifications. One key element in families' choice is the exterior appearance of the lamb, which should show a well developed pair of horns. Therefore, strategies for the genetic improvement of sheep should take into account these requirements, particularly breed standards and thus avoid crossbreeding with hornless animals as their products would not be accepted for that specific market.

The previous remarks show that sheep production in Morocco has been facing increasing challenges. On the one hand, it has lost its 'natural' status, as a growing number of flocks rely on off-farm feed resources. This implies growing tensions on rangeland resources, particularly in arid areas. On the other hand, the demand for sheep products has been falling, as it is not competitive anymore with poultry products and beef. This trend is clearly illustrated by the projection of the demand by 2025 (ADA, 2008). These trends show that the levels of mutton consumption are expected to remain constant, and most of the increases in the consumption of animal proteins should come from poultry, dairy products and also beef (Table II).

However, sheep hold a strong identity role, as they are associated to important feasts, mainly the Aïd El Kébir. Therefore, sustained efforts to promote sheep production in Morocco are needed. They should primarily focus on capturing consumers' interest by the promotion of their organic and green status in comparison to livestock from intensive systems (dairy cattle and poultry). To do so, traceability will be necessary to reward sheep breeders in remote areas, who have to face harsh conditions in comparison to flocks raised mainly with concentrates in suburban belts. To ensure that traceability and increase the income of extensive sheep systems, an improvement of the whole governance within that chain must be implemented: from input suppliers to breeders, retailers,

\section{Table I}

Relationship between the use of cereal grains and mutton and milk prices in Morocco in 2000

\begin{tabular}{|c|c|c|c|c|}
\hline \multirow{2}{*}{$\begin{array}{l}\text { Concentrate } \\
\text { to total energy } \\
\text { intake }(\%)\end{array}$} & \multirow{2}{*}{$\begin{array}{c}\text { Type of } \\
\text { concentrate }\end{array}$} & \multicolumn{3}{|c|}{ Price comparison } \\
\hline & & $\begin{array}{l}\text { Milk/ } \\
\text { Barley }\end{array}$ & $\begin{array}{c}\text { Mutton/ } \\
\text { Barley }\end{array}$ & $\begin{array}{l}\text { Beef/ } \\
\text { Barley }\end{array}$ \\
\hline 15 & Barley, wheat bran & 1.5 & 30 & 25 \\
\hline
\end{tabular}

Adapted from Alary and Boutonnet, 2006

\section{Table II}

Projected levels of animal product consumption by 2025 in comparison with 2005

\begin{tabular}{lc} 
Animal products & Consumption levels by year 2025 \\
\hline Milk & Increase by 200 to $300 \%$ \\
Meat (all species) & Increase by $130 \%$ \\
Beef & Increase by $100 \%$ \\
Mutton and goat & Same level \\
Poultry meat & Increase by $150 \%$
\end{tabular}

Adapted from the Agricultural Development Agency, 2008 
supermarkets and consumers' organizations. This improvement might be the prerequisite to ensuring the sustainability of extensive sheep farming.

\section{CONCLUSION}

The ongoing changes in the social demand for animal products in Morocco have created a situation in which products from extensive systems appear to be losing ground to commodities generated by intensive systems. In fact, the demand has shifted toward broiler meat and dairy preparations, which are more suited to the offer from fast-food outlets than mutton and goat meat. Therefore, local authorities have promoted several measures to develop intensive systems by helping private poultry operators build modern facilities and implementing a dairy plan in the large scale irrigation schemes.

The initial results have been satisfactory as the output of broiler meat, eggs and milk has increased significantly. However, an assessment of these increases reveals that they rely on intensive imports of inputs, like feed grains and protein meals, and also genes (heifers, chicks, and artificial insemination straws). Moreover, these intensive cattle and poultry systems are concentrated in specific areas, causing serious environmental concerns. For example, dairy farming requires important volumes of water and, therefore, even in irrigated areas it contributes to groundwater depletion in several regions of the country. This is a serious concern in the majority of irrigation schemes located in arid and semiarid areas where water stress is progressively causing the exodus of large dairy farms to more favorable areas in the north of the country. Another concern is the use of pesticides to increase fodder biomass, mainly through maize silage. Pesticide residues contaminate milk but their impacts on consumers, however, seem to be ignored by the operators of the dairy chain, from dairy farmers to milk processors and, above all, consumers themselves.

In order to promote the emergence of environmental issues within animal product supply chains, there must be a change in the methodological approaches used. More systemic methods should be adopted as they would include not only the comparison of animal product prices, but also their environmental footprint (energy and water needs mainly in a country with no fossil oil and with acute water stress), and their social cost. Such a systemic approach might prompt significant changes in the roles of extensive livestock systems located in the marginal areas of the country. Currently they have lost their prestige as they could not meet the growing needs for animal proteins in big cities. However, given the organic status of most products originating from rangelands (above all sheep and goat meat), they could gain ground among well-informed consumers who wish to avoid environmental and health risks associated to products from intensive systems. Such a change could be vital to the resilience of extensive livestock systems, as it would also help increase farmers' income and rehabilitate marginal areas, which face today important challenges such as unsustainable rhythms of resource use (mainly forests and water), pauperization and rural exodus.

To avoid the exacerbation of such problems and promote the harmonized development of rangelands, traceability of their products must be implemented. This will encourage many consumers who have become aware of the benefits of such products to consent to pay higher prices. This should only reward the efforts of livestock breeders in remote areas, who often have to face harsh conditions.

To achieve all these goals and balance the value repartition within the supply chains of extensive livestock systems, the adoption of good governance principles will be mandatory. That could only be achieved with the responsible implication of all the actors (breeders' associations, retailers, consumers and State authorities), who have to be made aware of the crucial importance of this issue: rescuing extensive livestock systems in order to decrease the dependence on imported inputs and promote a sound social and economic development of the vast pastoral areas of the country. This would also reduce to a certain extent the consequences of recurring food price surges in global markets on the food supply to the population.

\section{REFERENCES}

Agricultural Development Agency, 2008. The Green Morocco Plan. Rabat, Morocco. www.ada.gov.ma/en/Plan_Maroc_Vert/plan-marocvert.php

Alary V., Boutonnet J.-P., 2006. L'élevage ovin dans I'économie des pays du Maghreb : un secteur en pleine évolution. Sécheresse, 17 : 40-46

Allan J.A., 1998. Virtual water: a strategic resource - global solutions to regional deficits, Groundwater, 36: 545-546

Blinda M., Thivet G., 2009. Ressources et demandes en eau en Méditerranée : situation et perspectives. Sécheresse, 20 : 9-16

Boulanouar B., Paquay R., éds, 2005. L'élevage du mouton et ses systèmes de production au Maroc. INRA éditions, Rabat, Maroc

Bourbouze A., 1997. Des agdals et des mouflons. Protection des ressources et (ou) développement rural dans le parc naturel du Haut Atlas oriental (Maroc). Courr. Environ. INRA, $30: 29-37$

Catin M., Hanchane S., Kamal A., 2007. Structure industrielle externalités dynamiques et croissance locale au Maroc. Rég. Dév., 25 : 45-63

Chapagain A.K., Hoekstra A.Y., 2004. Water footprints of Nations. Value of water. UNESCO-IHE, Delft, Netherlands. (Res. Rep. Ser. No 16)

Chiche J., 2008. Les nouvelles stratégies et les perspectives de l'élevage traditionnel au Maroc dans le contexte de la mondialisation. Options Méditerr., $78: 71-77$

FAO, 2010. FAO Stat database: Morocco's agricultural commodities' production. http://faostat.fao.org/site/339/default.aspx

FIS, 2008. Documents and statistics. Fédération interprofessionnelle du secteur avicole. www.fisa.org.ma/documentation.asp

Flamant J.C., 2002. Histoires de races animales, histoire de sociétés humaines. Mission d'animation des agrobiosciences. Castanet Tolosan, France, ENFA

Haddada B., Ponter A.A., Mezzane H., Mialot J.P., Ponsart C., Grimard B., 2003. Santa Gertrudis cows under Moroccan range conditions: evolution in metabolic characteristics. Rev. Méd. Vét., 154: 611-618

Hammani A., Hartani T., Kuper M., Imache A., 2009. Paving the way for groundwater use: Transforming information for crafting management rules. Irrig. Drain., 58: S240-S251

Lakrakeze J., 1993. Famines et épidémies au Maroc mérinide et saadien du XIII e ${ }^{\mathrm{e}}$ XVII siècles. Thèse Doct., Université Toulouse le Mirail, France

Le Gal P.-Y., Kuper M., Moulin C.-H., Sraïri M.T., Rhouma A., 2009. Linking water saving and productivity to agro-food supply chains: a synthesis from two North African cases. Irrig. Drain., 58: S320-S333

Miège J.L., 1961. Le Maroc et I'Europe, 1830-1894, tome II : L'ouverture. Presses universitaires de France, Paris, 588 p.

Office of Currency Change, 2013. Foreign trade statistics. Rabat, Morocco. www.oc.gov.ma/BALANCE\%20COMMERCIALE

Rguibi M., Belahsen R., 2007. Prevalence of obesity in Morocco. Obes. Rev., 8: 11-13

Sarter G., 2006. Manger et élever des moutons au Maroc. Sociologie des préférences et des pratiques de consommation et de production de viande. Thèse Doct., Université Paris I, France, 305 p. 
Speedy A.W., 2003. Global production and consumption of animal source foods. J. Nut., 133: 4048S-4053S

Sraïri M.T., 2011. Le développement de l'élevage au Maroc : succès relatifs et dépendance alimentaire. Courr. Environ. INRA, 60 : 91-101

Sraïri M.T., Benhouda H., Kuper M., Le Gal P.-Y., 2009a. Effect of cattle management practices on farms operating in a two stage dairy chain. Trop. Anim. Health Prod., 41: 259-272

Sraïri M.T., El Jaouhari M., Saydi A., Kuper M., Le Gal P.-Y., 2011. Supporting small scale dairy farmers in increasing milk production: evidence from Morocco. Trop. Anim. Health Prod., 43: 41-49
Sraïri M.T., Kiade N., Lyoubi R., Messad S., Faye B., 2009b. A comparison of dairy cattle systems in an irrigated perimeter and in a suburban region: case study from Morocco. Trop. Anim. Health Prod., 41: 835-843

Sraïri M.T., Rjafallah M., Kuper M., Le Gal P.-Y., 2009c. Water productivity through dual purpose (milk and meat) herds in the Tadla irrigation scheme, Morocco. Irrig. Drain., 58: S334-S345

Tillon G., 2000. Il était une fois l'ethnographie. Seuil, Paris, France

Vaysse J., 1952. L'élevage au Maroc, 35 années d'expérience zootechnique et de protection du cheptel, vol. 1, Ruminants. La Terre Marocaine, Rabat, Morocco

\section{Résumé}

Sraïr M.T. Elevage extensif au Maroc : des territoires marginaux aux rôles essentiels socio-environnementaux

Les évolutions récentes de l'approvisionnement en produits animaux au Maroc ont montré une nette diminution de la contribution des élevages extensifs. Dans un contexte de forte croissance démographique (de 15,3 à 32,9 millions d'habitants entre 1956 et 2013) associée à une urbanisation rapide (près de $60 \%$ de la population vit dans des centres urbains), les habitudes alimentaires ont clairement évolué. La structure patriarcale de la société, où les repas étaient consommés collectivement à la maison, a été remplacée par des comportements plus individualistes. Par conséquent, la nature des produits animaux consommés par de grands pans de la population a changé. Les produits laitiers et à base de volaille apparaissent les mieux adaptés à ces changements car ils s'incorporent aisément aux repas rapides. D'un autre côté, la consommation de viande de bœuf et de mouton provenant des systèmes extensifs n'a pas évolué. Ces systèmes permettent cependant de valoriser de nombreux aliments riches en fibres, comme les ressources pastorales et les coproduits de la céréaliculture. Ceci leur a traditionnellement permis d'assurer des fonctions stratégiques comme le développement régional de zones marginales, la gestion des ressources naturelles, la valorisation efficace de l'eau à travers les produits d'élevage dans un pays affecté par des pénuries d'eau aiguës, et la création de richesses et d'opportunités d'emploi. Le fait que ces systèmes d'élevage extensifs aient été délaissés au profit de systèmes plus intensifs soulève de nombreuses questions. Ces derniers ajoutent une immense pression sur les ressources naturelles des zones où la production intensive est concentrée. Cela signifie aussi que l'approvisionnement en produits animaux s'est fortement fragilisé car il dépend d'intrants importés, comme des gènes animaux et des produits alimentaires (soja et maïs pour la volaille). Ces évolutions nécessitent que plus d'attention soit accordée aux systèmes d'élevage extensif car ils assurent un mode de production écologique tout en valorisant de grands espaces ruraux. Ces systèmes tiendront un rôle stratégique essentiel dans un avenir proche lorsque les questions de durabilité de l'approvisionnement en protéines animales et de préservation des ressources naturelles deviendront pressantes, et pour permettre le développement équilibré des différentes régions du pays.

Mots-clés: ovin, volaille, bovin laitier, pastoralisme, élevage extensif, qualité des produits, agriculture intensive, race, Maroc

\section{Resumen}

Sraïri M.T. Ganadería extensiva en Marruecos: de territorios marginales a roles sociales y ambientales mayores

Desarrollos recientes en los suministros de productos animales en Marruecos revelaron una disminución aguda de la contribución de los sistemas de ganadería extensiva. En el contexto de una marcada expansión demográfica (de 15,3 a 32,9 millones de habitantes de 1956 a 2013) asociada a una urbanización rápida (casi $60 \%$ de la población vive en centros urbanos), los hábitos de consumo han cambiado. Ha habido un cambio de una estructura patriarcal de la sociedad, que significaba que las comidas se consumían en el hogar, hacia comportamientos más individualistas. Como consecuencia, la naturaleza de los productos animales consumidos por largas porciones de la población han cambiado notablemente. Los productos lácteos y avícolas parecen ser los mejores adaptados a estos cambios, ya que pueden ser utilizados en preparaciones de comidas rápidas. Al otro extremo, el consumo de res y ovino provenientes de sistemas extensivos se ha estancado. Sin embargo, los sistemas de producción extensiva, utilizan todavía una vasta cantidad de alimentos fibrosos, desde recursos provenientes de pastizales hasta sub productos de cereales. Tradicionalmente, esto les ha permitido asegurar funciones estratégicas como el desarrollo regional de áreas marginales, manejo de recursos naturales, productividad eficiente de agua a través los productos de ganadería, en un país que experimenta una escasez aguda de agua, así como la creación de riqueza y oportunidades laborales. El cambio de intereses de estos sistemas a unos más intensivos, plantea sin embargo muchas preguntas. Pone tremenda presión en los recursos naturales en áreas donde la producción intensiva está concentrada. Significa también que el suministro de productos animales es altamente frágil, debido a que depende de insumos importados, desde genes animales hasta alimentos (soja y maíz para aves). Estos cambios significan que se debe dar más atención a los sistemas de producción ganadera extensiva, ya que promueven una vía más ecológica de producción y promueve las grandes áreas rurales. Estos sistemas podrían sostener una posición estratégica en el futuro próximo, cuando venga el momento de enfrentar situaciones como la sustentabilidad del suministro de proteína animal y la preservación de los recursos naturales, así como asegurar un desarrollo balanceado de las diversas regiones del país.

Palabras clave: ovino, aves de corral, ganado de leche, pastoralismo, ganadería extensiva, calidad del producto, explotación agrícola intensiva, raza, Marruecos 